\title{
Roles of the Exogenous $\mathrm{H}_{2} \mathrm{~S}$-Mediated SR-A Signaling Pathway in Renal Ische...ia , Reperfusion Injury in Regulating Endoplasmic Reticulum Stress-Induc Autophagy in a Rat Model
}

\author{
Qing Ling Xiao Yu Tao Wang Shao-Gang Wang \\ Department of Urology, Tongji Hospital, Tongji Medical College, Huaz, \\ Technology, Wuhan, P.R. China

\section{Key Words} \\ Exogenous hydrogen sulfide $\cdot$ SR-A signaling $\mathrm{p}$ \\ Endoplasmic reticulum stress $•$ Autophagy $\bullet$ Regu
} ay ischemia/reperfusion injury •
- G a knockout

\section{Abstract}

Objective: This study aims to lore mediated scavenger receptor $A(S P$ sis (IRI) by regulating endoplaamic re total of 48 normal Sprague into six groups $(\mathrm{n}=8)$ : wil NaHS, SR-A ${ }^{-1-}+$ sham, protein, blood urea ni in renal tissue were $d$ and protein leyraf IL genes. A TU' to observe 2 group, MDP entra

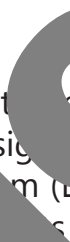
ffec $f$ the exogenous hydrogen sulfide $\left(\mathrm{H}_{2} \mathrm{~S}\right)$ thway on renal ischemia/reperfusion injury $-y(S$. tress-induced autophagy in rats. Methods: A and $S R-A$ knockout rats were selected and divided (WT) ,ham, WT + ischemia-reperfusion (I/R), WT + I/R + SR $-A^{-/}+\mathrm{I} / \mathrm{R}+\mathrm{NaHS}$. The concentrations of urinary gen (BUN, serum creatinine (SCR), malondialdehyde (MDA) and $\mathrm{H}_{2} \mathrm{~S}$ ted $\mathrm{Y}$ T-PCR and Western blotting were used to detect the mRNA , SR-A, LC3I, LC3II, P62, PERK, ATF6 and IRE1 pathway-related was used to detect cell apoptosis. Electron microscopy was applied of renal autophagosomes. Results: Compared with the WT + sham the WT + I/R group, the urine volume, urinary protein, BUN, SCR and , the mRNA and protein expression of IL-6, TGF- $\beta$, LC3II/I, and ER stress 'ated genes, the cell apoptosis index, and the number of autophagosomes were ifican. creased $24 \mathrm{~h}$ after I/R, while P62 and SR-A protein expression and SOD and $\mathrm{H}_{2} \mathrm{~S}$ ontratiuns were significantly decreased (all $P<0.05$ ). The levels of renal injury, autophagy an ess pathway-related genes were decreased in the WT $+I / R+N a H S$ group but were ncreased in the $\mathrm{SR}-\mathrm{A}^{-/}+\mathrm{I} / \mathrm{R}$ group relative to the $\mathrm{WT}+\mathrm{I} / \mathrm{R}$ group. No significant differences e observed in the urine volume; the concentrations of urinary protein, BUN, SCR and MDA; 1e SOD activity; the mRNA and protein expression of IL-6, TGF- $\beta$, SR-A, GRP78, SR-A, GPR94, ATF4, IRE1, XBP1, ATF6, and eIF2 $\alpha$; the cell apoptosis index; or the number of autophagosomes in rats of the SR-A $\mathrm{A}^{--}+\mathrm{I} / \mathrm{R}$ and $\mathrm{SR}-\mathrm{A}^{-\%}+\mathrm{I} / \mathrm{R}+\mathrm{NaHS}$ groups (all $P>0.05$ ). Conclusion: These results demonstrate that the exogenous $\mathrm{H}_{2} \mathrm{~S}$-mediated SR-A signaling pathway reduces renal IRI injury by up-regulating ER stress-induced autophagy in rats. 


\section{Introduction}

Renal ischemic-reperfusion injury (IRI) is a typical complication of organ transplantation, leading to adenosine triphosphate (ATP) depletion, accumulation of toxic metabolites, and consequent tissue damage [1]. During the process of renal transplantation, transient cessation in renal blood flow leads to acute ischemic insult, and the reperfusion further deepens the functional and structural damage to the human kidney [2]. There are two basic mechanism that underlie IRI, namely, the systemic imbalance of oxidative stress and the immun inflammatory response caused by restoration of metabolic processes [3]. For 1 graft function (DGF) and initial poor graft function (IPGF) are both common events are reported to influence approximately $25 \%$ of the renal tissue from decea Currently, effective therapeutic regimens for the prevention of renal IRI are u. It has been proven that propofol, COX metabolites and MiR-155 can mediat but researchers have focused their attention on the attenuation of endat (ER) stress and autophagy for their therapeutic potential [9-11].

The ER plays a pivotal role in protein folding and synthes' $\mathrm{d}$ in calc. $\mathrm{Ca}^{2+}$ ) storage and signaling [12]. ER stress occurs if the ER environmen (glycosylation) is disturbed, which inevitably leads to the reg of PERK kinase (or cell eIF2a kinase) and GRP78 [13]. The ER resident PKK nàs (PERK) plays an important role in Akt activation in response to ER stress I- Researchers have also demonstrated that hepatic eukaryotic initiation factor 2 (eIF2a) critical to the insulininduced ER stress [15]. GRP78 (glucose-regulated $78 \mathrm{kDa}$ ) is an ER chaperone, facilitating Ca2+ binding and regulating ER str slg protein quality control, and protein folding and assembly [16]. IRI can induc stres y perturbing $\mathrm{Ca}^{2+}$ homeostasis, resulting in the accumulation of misfolded mein stress also enhances apoptosis and aggravates cell damage [17]. Moreover le,s to the potentiation of autophagy, which determines the fate of "s [18] flam, ion is a direct result of tissue injury and can also lead to ER stress via t... plammatory factors and the generation of reactive oxygen species (ROS) [1 macrophage scavenger receptor (SR-A) is a prototypic member of the ger tor (SR) family, a collection of membrane receptors [20]. In recent years, seve dies $h$ revealed that SR-A has an essential influence on inflammation, ERS and $\quad[21,22]$. Hydrogen sulfide $\left(\mathrm{H}_{2} \mathrm{~S}\right)$, synthesized in the metabolic pathway th egulate. tissue concentration of sulfur-containing amino acids, is an endogenous gas s mer $r^{\prime}$ tor that exerts effects in the central nervous system and the cardiovascular srctem. cudy by Ji et al. has demonstrated that exogenous $\mathrm{H}_{2} \mathrm{~S}$ postconditioning essiuny prevent the rat heart from experiencing IRI [24]. In addition, $\mathrm{H}_{2} \mathrm{~S}$ is regar do dogenous signaling molecule which exerts cardio-protection against MIRI in dia vo and also known as a powerful neuro-protective agent in the central nerv sten 26]. Therefore, the present study was conducted to explore the effects

\section{of the enous $\mathrm{H}_{2} \mathrm{~S}$-mediated SR-A signaling pathway on renal IRI by regulating ER stress-
acea hagy in rats. \\ of the enous $\mathrm{H}_{2} \mathrm{~S}$-mediated SR-A signaling pathway on renal IRI by regulating ER stress-
acea}

\section{Irraterials and Methods}

Ethics statement

The experiment was approved by the Institutional Animal Care and Use Committee (IACUC) of Tongji Hospital, Tongji Medical College, Huazhong University of Science \& Technology.

\section{Subjects and grouping}

A total of 48 rats ( 5 to 6 months of age, weighing from 200 to 240 g), including healthy Sprague-Dawley (SD) rats and rats with $S R$ - $A$ gene knockout, were provided by Shanghai Research Center for Southern Model Organisms. The Center also confirmed the genotypes of rats with $S R-A$ gene knockout. The experimental rats were given free access to conventional pellets and drinking water and were kept under a regular 12-h 
circadian rhythm at $18 \sim 22^{\circ} \mathrm{C}$ with good ventilation. Before the experiment, the rats were kept for one week to adapt to the environment and were then divided into six groups $(n=8)$ : the wild-type and shamoperation group (the WT + sham group); the wild-type and ischemia-reperfusion group (the WT $+\mathrm{I} / \mathrm{R}$ group); the wild-type and ischemia-reperfusion with NaHS therapy group (the WT + I/R + NaHS group); the $S R-A$ gene knockout and sham-operation group (the SR-A ${ }^{-}+$sham group); the $S R-A$ gene knockout and ischemia-reperfusion group (the SR-A $\%+\mathrm{I} / \mathrm{R}$ group); and the $S R-A$ gene knockout and ischemia-reperfusion with NaHS therapy group (SR-A ${ }^{-1}+\mathrm{I} / \mathrm{R}+\mathrm{NaHS}$ group).

\section{Renal IRI}

The rats were anesthetized by intraperitoneal injection of $6 \%$ chloral hydrate $(0.5 \mathrm{ml} / 100 \mathrm{~g}$, S Chemical Reagent Co., Ltd., Shanghai, China) and placed on the operating table, where disinfected with $75 \%$ ethyl alcohol. A $2 \mathrm{~cm}$ incision was made on both sides of the spine c. twelfth rib. Then, the muscle and fascia were separated, the kidney was exposed, and b' conducted on the renal pedicle. The renal artery was blocked by a non-invasive vascular the clamp was removed, and the time of reperfusion was recorded. The rats were pu. fed as usual, with the incisions sutured and sterilized. The status of th was obs For rats in the $\mathrm{WT}+$ sham and SR-A $\%$ + sham groups, the bilateral renal artery was 5 thout thelar clamp, but the other experimental steps were conducted as described above. ats T $+\mathrm{I} / \mathrm{R}+\mathrm{NaHS}$ and $\mathrm{SR}-\mathrm{A}^{--}+\mathrm{I} / \mathrm{R}+\mathrm{NaHS}$ groups, after $50 \mathrm{~min}$ of ischemia, intraperitoneal in, Chemical Co., Ltd, St. Louis, MO, USA) was carried out. In this experiment, u vas collected before surgery $(0 \mathrm{~h})$ and reperfusion for $24 \mathrm{~h}$. Blood and renal tissues were removed $24 \mathrm{~h}$ a. eperfusion [1].

\section{Collection of urine, plasma and renal tissues}

Before surgery, the rats in the 6 groups were put in and designated $0 \mathrm{~h}$. Then, the rats were put into the molih. abolı cages; $24 \mathrm{~h}$ later, urine was collected es after I/R; 24 h later, urine was collected, and the urine volume was recorded. After the el separately, intraperitoneal injection of $6 \%$ chloral hydrate was performed anestr and enterocoelia was exposed to allow removal of a of $5000 \mathrm{rpm}$ and $4^{\circ} \mathrm{C}$ for $10 \mathrm{~min}$. After tubes and kept at $-80^{\circ} \mathrm{C}$.. Twe ho or I/R, the bilateral renal tissues were separated; one was immersed in $4 \%$ formalin for fy overnis and the other was put into an EP tube with liquid nitrogen and saved at $-80^{\circ} \mathrm{C}$. There y tern group.

Province, Chin $\quad$ in detection kit (Nanjing Jiancheng Bioengineering Institute (Jiangsu samples and ge incubated for $5 \mathrm{~min}$, and the absorbance values in all tubes were detected at the waveleng of $59 \mathrm{~m}$ concentration of urine protein $(\mathrm{mg} / \mathrm{L})=$ (the absorbance value in the testing tube/ sorba lue in the standard tube) $\times$ the standard concentration of protein. The 24-hour praten thas calculated as the concentration of urine protein $\times$ the 24 -hour urine volume. There ten each group.

Ir accordance with the specifications of the BUN determination kit (Rongsheng Biotech, Shanghai, ina), the BUN concentration in the serum was analyzed using the urease continuous monitoring assay. e mixtures of samples and reagents were colorimetrically assessed using a spectrophotometer. The value at $30 \mathrm{~s}$ (A1) and the value at $90 \mathrm{~s}$ (A2) were recorded. The concentration of BUN $(\mathrm{mmol} / \mathrm{L})=($ the absorbance at $\mathrm{A} 2$ of the sample tube - the absorbance at A1 of the sample tube)/(the absorbance at A2 of the calibration solution - the absorbance at $\mathrm{A} 1$ of the calibration solution) $\times$ the concentration of standard solution.

\section{Concentration of serum creatinine (SCR)}

Following the specifications of the SCR kit (Rongsheng Biotech, Shanghai, China), the concentration of SCR was analyzed by the picric acid method. The specimens were mixed with the reagent and placed in a water bath at $37^{\circ} \mathrm{C}$ for $30 \mathrm{~s}$. The initial absorbance (A1) at $0 \mathrm{~s}$ in a blank tube and the terminal absorbance 


\section{Cellular Physiology Cell Physiol Biochem 2017;41:2461-2474

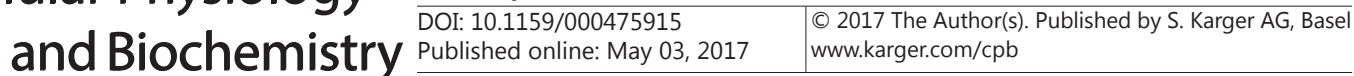

Ling et al.: $\mathrm{H}_{2} \mathrm{~S} \& \mathrm{SR}$-a Reduce Ischemia/Reperfusion Injury

(A2) at $90 \mathrm{~s}$ were recorded at a wavelength of $505 \mathrm{~nm}$. The concentration of SCR $(\mu \mathrm{mol} / \mathrm{L})=($ the absorbance at A2 of the sample tube - the absorbance at A1 of the sample tube)/(the absorbance at A2 of the calibration solution - the absorbance at A1 of the calibration solution) $\times$ the concentration of the standard solution. There were ten rats in each group.

\section{Content of renal malondialdehyde (MDA)}

The MDA content in the rat kidneys was measured using an MDA kit (Nanjing Jiancheng Bioengineerin Institute) and the thiobarbituric acid (TBA) method [27]. After mixing with the reagent, the ronal prote samples were placed in a water bath at $95^{\circ} \mathrm{C}$ for $40 \mathrm{~min}$, cooled with running water and cent. rate of $3500 \mathrm{rpm}$ for $10 \mathrm{~min}$. The absorbance values in all tubes were detected at the wavelength $c$ The concentration of MDA $(\mathrm{nmol} / \mathrm{ml})=($ the absorbance in the testing tube - the absorba $;$ the blank tube)/(the absorbance in the standard tube - the absorbance in the standard blank concentration $(10 \mathrm{nmol} / \mathrm{ml}) \times$ the dilution ratio of the sample before the test. There war group.

Content of superoxide dismutase (SOD)

The renal SOD content in rats was detected using a SOD $\mathrm{k}$ Institute). The renal protein samples were mixed with the reagent. Aft absorbance at the wavelength of $450 \mathrm{~nm}$ was measured. In this reaction $(\mathrm{U})$ equals the enzyme quantity at the moment when the SOD inhibition rà rate $=\{($ control A - blank control A $)-($ testing A - blank testing A $)\} \times 100 /(c$ activity $(\mathrm{U} / \mathrm{ml})=$ SOD inhibition rate $/ 50 \% \times$ dilution ratio $\quad$ on system $/$ the concentration of sample protein to be tested. There were ten rats in each group.

Concentration of hydrogen sulfide $\left(\mathrm{H}_{2} \mathrm{~S}\right)$

The content of $\mathrm{H}_{2} \mathrm{~S}$ in renal tissues was phosphate-buffer saline (PBS) usin electr I/R $24 \mathrm{~h}$ prior was placed into a $2 \mathrm{mi}$ t he, a $\mathrm{ml}$ of double distilled water, $0.1 \mathrm{ml}$ of $\mathrm{m}$ solution $(0.067 \mathrm{ml})$ and $30 \mathrm{mV}$ hlo, Lution $(0.067 \mathrm{ml})$ were added, and the tissue was immersed in a water bath at $25^{\circ} \mathrm{C}$ for 20 cents at $6000 \mathrm{rpm}$ for $5 \mathrm{~min}$. Absorbance at the wave length of $670 \mathrm{~nm}$ was measured $\mathrm{r}$ reader, and the protein concentration was determined by the BCA kit (Boster Biotechn y Co., Ltu nan, China). The concentration of $\mathrm{H}_{2} \mathrm{~S}$ in the renal tissue ( $\mu \mathrm{mol} /$ gpr) = the concentration $\quad S$ in a"specimens/protein concentration. There were ten rats in each group.

\section{Western $b$}

A BCA 1 (B. chnology Co., Ltd., Wuhan, China) was used to test the protein concentration in rat kic vs $(5$ g) . $\mathrm{h}$ had undergone I/R. The extracted protein was boiled with loading buffer at $95^{\circ} \mathrm{C}$ lin, an $\mathrm{g}$ was loaded into each well. Then, the protein underwent $10 \%$ polyacrylamide gel electro sis at $80 \mathrm{~V}$ and then at $120 \mathrm{~V}$, followed by wet transfer onto polyvinylidene fluoride (PVDF) at $\mathrm{mV}$ h $70 \mathrm{~min}$. After blocking at room temperature with $5 \%$ bovine serum albumin (BSA) for 1 mary a ar abodies against interleukin-6 (IL-6, 1:1000, Cell Signaling Technologies, Beverly, MA,USA), g growth factor-beta (TGF- $\beta, 1: 1000$, CST), SR-A (1:1000, Abcam, Cambridge, MA, USA), LC3I 1:500, Abcam, Cambridge, MA, USA), microtubule associated protein 1 light chain 3 alpha (LC3II, 1:500, cam, Cambridge, MA, USA) or P62 (1:1500, Abcam, Cambridge, MA, USA) were added, and then the embranes were incubated overnight at $4{ }^{\circ} \mathrm{C} .$. After rinsing with Tris-buffered saline with Tween (TBST) three times for $5 \mathrm{~min}$ per wash, the corresponding secondary antibody was added and incubated for $1 \mathrm{~h}$. Then, the membrane was washed three times for 5 min per wash and developed by chemiluminescence reagents. Phosphoglyceraldehyde dehydrogenase (GAPDH) was used as an internal reference 1:5000, Kangcheng Biology Engineering Co., Ltd., Shanghai, China). Each group was repeated three times. A Bio-Rad Gel Doc EZ imager (Gel doc ez imager, Bio-Rad, California, USA) was used for developing. The gray values of the target bands were analyzed with Image J software. These procedures were repeated five times for all groups.

\section{KARGER}


Table 1. The primer design of qRT-PCR. Notes RT-qPCR, real-time quantitative polymerase chain reaction; GAPDH, glyceraldehyde phosphate dehydrogenase; IL-6, interleukin-6; TGF- $\beta$, transforming growth factor- $\beta$; SR-A, scavenger receptor A; GRP78, heat shock protein family a member 5; eIF2 $\alpha$, eukaryotic translation initiation factor 2 subunit alpha; LC3 II, microtubule associated protein 1 light chain 3 alpha II

\begin{tabular}{ll}
\hline PCR primers sequences & Forward (5'-3') \\
\hline GAPDH & CCATTTGCAGTGGCAAAG \\
IL-6 & ATGAACTCCCTCTTCAC \\
TGF- $\beta$ & ATGCCGCCTTCGGGGCTGCGGCTGCTGC \\
SR-A & CTCCTGAAGTGGGAAACGAAG \\
GRP78 & ATCACGCCGTCCTATGTCGC \\
GPR94 & CTTCGCTTCCAGTCTTCCCATC \\
IRE1 & TGAGGGCAATGAGAAATAAGAAGC \\
ATF4 & TTGATGCCCTGTTAGGTATGGAA \\
XBP1 & GCGAGTCTACGGATGTGAAGGA \\
ATF6 & GATTGTGGGCGTCACTTCTCG \\
eIF2 $\alpha$ & TTTAAGGGAGTGGCTTGATTT \\
\hline
\end{tabular}

Quantitative real-time fluorescence PCR ( $q R T-P C R$ )

As shown in Table 1, total RNA from $24 \mathrm{~h} \mathrm{I/R}$ rat kidneys (approxim Reverse (5'-3')

CACCCCATTTGATGTTAGTG CTACTTCATCCGAATAGCTC TCAGCTGCACTTGCAGGA CACGA GAGGTTGGCTTCCATGTCT. TСТСССССТСССТСТTАТСС AGAAGGCGTTCAAC TGTAGGAGCAGGTGA GGTATGAGTGGAC Vे C"I TGTGGAGGTT $C$ GAATG. TGGFATGCCAA $\quad$ GCCTG P $=$ TC n RNA extraction kit (Promega Co., Madison, WI, USA). The OD260/280 $30 \mathrm{mg}$ ) was extracted using of all RNA samples were tested using an ultraviolet spectrophotometer, and the conc ion of RNA ras calculated. The RNA was then preserved at $-80^{\circ} \mathrm{C}$ for further use. Reverse transcripti procedures of the RNA RT-PCR Kit (Promega Co., Mac WI, 6 A two-step reaction sequence was adopted for PCR: initial denaturation at $95^{\circ} \mathrm{C}$ for $15 \mathrm{~min}$, hen 40 cycles of the following conditions: denaturation at $95^{\circ} \mathrm{C}$ for $10 \mathrm{~s}$, annealing at $60^{\circ}$ ana ension at $72^{\circ} \mathrm{C}$ for $30 \mathrm{~s}$. The PCR reaction included SYBR Green mix $12.5 \mu \mathrm{l}$, forward pri $1 \mu \mathrm{l}$, rse primer $1 \mu \mathrm{l}$, cDNA template $2 \mu \mathrm{l}$, and ddH2O $8.5 \mu \mathrm{l}$ (Promega, Madison, WI, USA th GAF an ernal reference, an amplification curve was used to evaluate the reliability of PCR. The calculated as $2^{-\Delta \Delta \mathrm{Ct}}$. These proc $r$ we, ated five times for all groups.

Terminal deoxynucleotidy

After the slices were $\mathrm{H}_{2} \mathrm{O}_{2}$ methanol solution $f$ box. TUNEL reagent was were put into a h rase me ated nick end labeling (TUNEL) assay

axed sted with $0.1 \%$ trypsin for $3 \mathrm{~min}$, they were incubated in $0.3 \%$ 0 min, treaced with $0.1 \%$ Triton $\mathrm{X}-100$ for $2 \mathrm{~min}$, and then placed in a humid ar cubated at $37^{\circ} \mathrm{C}$ for $1 \mathrm{~h}$ after two 5-min PBS washes. Then, the slices erter-POD at $37^{\circ} \mathrm{C}$ for $30 \mathrm{~min}$ and underwent DAB development at room temperature f er three 5-min PBS washes. This was followed by hematoxylin counterstaining, distilled water in g, ration, cover slipping and slice sealing. be ptotic cells. The percentage of apoptosis-positive cells in the renal tubule epithelia relative to total nu of renal tubule cells was taken as the apoptotic index (AI) of the renal tubule.

Approximately $1 \mathrm{~mm}^{3}$ of renal tissue sample was double fixed in $4 \%$ glutaraldehyde and $1 \%$ osmic . After gradient dehydration in acetone, a mixed resin/acetone liquor was added; $2 \mathrm{~h}$ later, the tissue was bedded in resin and baked at $65^{\circ} \mathrm{C}$ for $24 \mathrm{~h}$. After ultrathin slicing at a thickness of $50 \mathrm{~nm}$, uranyl acetate and lead citrate were used for double staining. A transmission electron microscope (TEM, HITACHI H-600) was employed to observe and photograph the ultra-microstructure.

\section{Statistical analysis}

All data in the experiment were analyzed by SPSS 21.0 integrated software (SPSS Inc. IBM, Chicago, IL, USA). Data are presented as the means \pm standard deviation (SD). The $t$ test was used for comparison between two groups whose data followed the normal distribution. One-way analysis of variance (ANOVA) was used for comparisons among groups, with $P<0.05$ indicating statistical significance.

\section{KARGER}




\section{Results}

Comparisons of urine volume and urine protein content after 24 h among the six groups

After measuring the urine volume of rats in each group, no significant difference was found in the urine volume of rats in any group at $0 \mathrm{~h}$ (all $P>0.05$ ). No significant difference in urine volume was observed $24 \mathrm{~h}$ after I/R between the SR-A $\%$ sham group and the WT + sham group $(P>0.05)$. Urine volume increased significantly $24 \mathrm{~h}$ after I/R in the WT $+\mathrm{I} / \mathrm{P}$ group compared with the WT + sham group $(P<0.01)$. The urine volume $24 \mathrm{~h}$ after I/R the WT + I/R group was markedly higher than that in the WT + I/R + NaHS, the and the SR-A ${ }^{-1}+\mathrm{I} / \mathrm{R}+\mathrm{NaHS}$ groups (all $P<0.01$ ), but the urine volume $24 \mathrm{~h}$ after $\mathrm{I}$, $\mathrm{WT}+\mathrm{I} / \mathrm{R}+\mathrm{NaHS}$ and the SR-A $\%+\mathrm{I} / \mathrm{R}$ groups was still evidently higher than ${ }_{7}+\mathrm{t}_{\mathrm{H}}$ + sham group (both $P<0.05$ ). There was no significant difference in urine vo. $\mathrm{I} / \mathrm{R}$ between the SR-A $\%+\mathrm{I} / \mathrm{R}+\mathrm{NaHS}$ and the WT + sham groups $(P>0.05) \rho \mathrm{T}$

Based on the results of urinary protein detection, no significant differe in the urine protein content of rats in any group at $0 \mathrm{~h}($ all $P>0.05)$. No cant difference in the urine protein content was observed $24 \mathrm{~h}$ after I/R bety the SR- ham and the $\mathrm{WT}+$ sham group $(P>0.05)$. Urine protein content increas to after I/R in the $\mathrm{WT}+\mathrm{I} / \mathrm{R}$ group compared with that in the WT + sham of $\mathrm{p}$ content in the $\mathrm{WT}+\mathrm{I} / \mathrm{R}$ group $24 \mathrm{~h}$ after I/R was markedly hig $+\mathrm{NaHS}$, the SR-A $\%+\mathrm{I} / \mathrm{R}$ and the SR-A $\%+\mathrm{I} / \mathrm{R}+\mathrm{NaHS}$ groups (all n i. at in the WT + I/R content $24 \mathrm{~h}$ after I/R in the WT $+\mathrm{I} / \mathrm{R}+\mathrm{NaHS}$ and the SR-A $\mathrm{A}^{--}+\mathrm{I} / \mathrm{h}$ jups was still evidently higher than that in the WT + sham group (both $P<$ There was no significant difference in the urine protein content between the SR-A ${ }^{-1}$ $>0.05$ ) (Table 3).

\section{Comparisons of concentrations of $B$}

There was a remarkable ir ease it the $\mathrm{WT}+\mathrm{I} / \mathrm{R}+\mathrm{NaHS}$ group, th. $\mathrm{S}^{\mathrm{n}}-\mathrm{A}^{-}$ $\mathrm{A}^{-/-}+\mathrm{I} / \mathrm{R}+\mathrm{NaHS}$ group when co. 0.05). The BUN and SCR c rat. vere reduced significantly in the WT + I/R + NaHS
group and the SR-A $\mathrm{A}^{-\%}+\mathrm{sh}$ group and the SR-A $\mathrm{A}^{--}+\mathrm{sh}$
$\mathrm{I} / \mathrm{R}$, while the concentr ous oup, the SR-A $\%+$ I/R group, and the SRd n WT + sham group $24 \mathrm{~h}$ after I/R (all $P<$

Table 2. The urin rolus

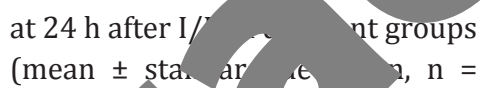

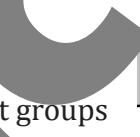
10). Not o h, or reatment; $24 \mathrm{~h}$ hafter mia/reper-

\begin{tabular}{lcc}
\hline & $0 \mathrm{~h}$ & $24 \mathrm{~h}$ \\
\hline WT + sham (ml) & $14.31 \pm 4.25$ & $13.01 \pm 3.19$ \\
WT + I/R(ml) & $12.15 \pm 2.91$ & $24.41 \pm 4.12^{\# \#}$ \\
WT + I/R + NaHS (ml) & $12.54 \pm 1.72$ & $18.98 \pm 3.19^{* * \#}$ \\
SR-A $/-$ sham (ml) & $13.92 \pm 3.11$ & $12.74 \pm 2.78^{* *}$ \\
SR-A $/-$ I/R (ml) & $15.78 \pm 5.33$ & $19.24 \pm 4.20^{* * \#}$ \\
SR-A $/-$ I/R + NaHS (ml) & $14.31 \pm 2.10$ & $16.05 \pm 3.98^{* *}$ \\
\hline
\end{tabular}

able 3. The discharge of urinary of rats at $24 \mathrm{~h}$ after I/R in different groups (mean \pm standard deviation, $\mathrm{n}=10$ ). Notes: $0 \mathrm{~h}$, before treatment; 24 , at 24 h after ischemia/reperfusion. Compared compared with the WT + I/R group, ${ }^{* *} P<0.01$

\begin{tabular}{lcc}
\hline & $0 \mathrm{~h}(\mathrm{ml})$ & $24 \mathrm{~h}(\mathrm{ml})$ \\
\hline $\mathrm{WT}+$ sham & $17.54 \pm 1.5$ & $19.89 \pm 1.01$ \\
$\mathrm{WT}+\mathrm{I} / \mathrm{R}$ & $18.33 \pm 1.98$ & $29.07 \pm 4.32^{\# \#}$ \\
$\mathrm{WT}+\mathrm{I} / \mathrm{R}+\mathrm{NaHS}$ & $18.52 \pm 2.63$ & $24.42 \pm 3.05^{* * \#}$ \\
$\mathrm{SR}-\mathrm{A}-/+$ sham & $17.25 \pm 1.94$ & $17.84 \pm 1.90^{* *}$ \\
$\mathrm{SR}-\mathrm{A}-$ - + I/R & $19.75 \pm 2.17$ & $25.12 \pm 4.73^{* * \#}$ \\
$\mathrm{SR}-\mathrm{A}-$ - + I/R + NaHS & $19.48 \pm 1.99$ & $20.97 \pm 1.68^{* *}$ \\
\hline
\end{tabular}

\section{KARGER}


Fig. 1. Detection of serum BUN, SCR, MDA, and SOD in rats of different groups $24 \mathrm{~h}$ after ischemia/reperfusion $(\mathrm{n}=8)$. Notes: A, The urease continuous monitoring assay was used to detect the BUN concentration $(\mathrm{mmol} / \mathrm{L})$ in rats from each group $24 \mathrm{~h}$ after ischemia/reperfusion. B, The picric acid method was used to detect SCR concentration (mmol/L) in rats from each group $24 \mathrm{~h}$ after ischemia/reperfusion. C, The thiobarbituric acid method was used to detect MDA concentration ( $\mathrm{nmol} / \mathrm{mg}$ ) in rats from each group $24 \mathrm{~h}$ after ischemia/reperfusion. D, Serum SOD activity $(\mathrm{U} / \mathrm{mL})$ was determined in rats from each group $24 \mathrm{~h}$ after ischemia/reperfusion. ${ }^{*} P$ $<0.05,{ }^{* *} P<0.01$ compared with the WT + sham group; ${ }^{\prime} P<0.05$, \#\# $P<0.01$ compared with the WT + I/R group; \& $P<0.05$ compared with the SR-A-/-+ I/R group.

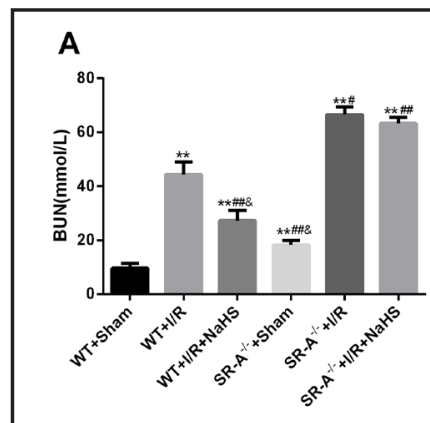

\section{B}

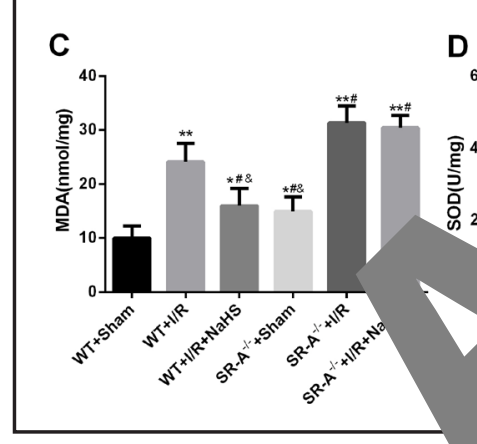

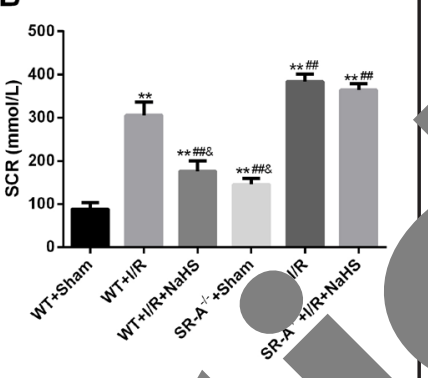

D

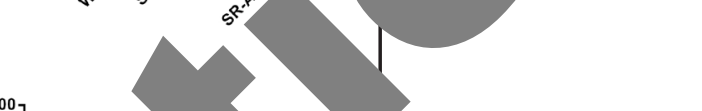

were apparently elevated (both $P<0.05$ ). The B + NaHS group were markedly decreased comp with $\quad$ SR-A $\%+$ IR group $24 \mathrm{~h}$ after I/R (all $P<0.05$ ). No significant differences in Bu SCR concentrations were observed between the SR-A ${ }^{-/}+\mathrm{I} / \mathrm{R}+\mathrm{NaHS}$ group $\quad$ R-A $/$ R group $(P>0.05)$ (Fig. 1A B).

The MDA concentration an SOD vity e significantly increased in the WT $+I / R$ group, the WT + I/R + NaHS g. p the $\%+$ am group, the SR-A $\%+$ I/R group, and the SR-A $\%+$ I/R + NaHS group com while the SOD activity wa ou creased (both $P<0.01$ ). The MDA concentration was significantly decrease the activity was markedly elevated in the WT + I/R + NaHS group and the (both $P<0.05$ ). The, conct ion was markedly decreased but the SOD activity was significantly increase the $\mathrm{SR}-\mathrm{A}^{-\%}+\mathrm{I} / \mathrm{R}+\mathrm{NaHS}$ and SR-A $\mathrm{A}^{-}+\mathrm{I} / \mathrm{R}$ groups compared with those in the WT $+\mathrm{I} / \mathrm{R} \quad(P<0.05)$. The MDA concentration in the WT + I/R + NaHS group was ap he SOD activity was lower when compared with the SR-A I- I/R grou $\mathrm{N}^{\mathrm{\gamma}} \quad$ re was no significant difference in SOD activity between the SR-A $\mathrm{A}^{-}+$ $\mathrm{I} / \mathrm{R}+\mathrm{N} \mathrm{N}^{-} \mathrm{S}$ gro a me SR-A $\%+\mathrm{I} / \mathrm{R}$ group (Fig. 1C D).

rison of $\mathrm{H}_{2} \mathrm{~S}$ concentration in renal tissue among the six groups

Thu concentration was significantly decreased in the WT + I/R group, the WT + I/R HS gro $p$, the SR-A ${ }^{-1}+$ sham group, the SR-A $\%+$ I/R group, and SR-A ${ }^{-}+\mathrm{I} / \mathrm{R}+\mathrm{NaHS}$ group $\mathrm{I} / \mathrm{R}$ in comparison with the WT + sham group $(P<0.05)$. The $\mathrm{H}_{2} \mathrm{~S}$ concentrations in tru $\checkmark \mathrm{T}+\mathrm{I} / \mathrm{R}+\mathrm{NaHS}$ group and the SR-A $\mathrm{A}^{-1}+$ sham group were significantly elevated
$-\mathrm{I} / \mathrm{R}$ group and the SR-A $-1-\mathrm{I} / \mathrm{R}+\mathrm{NaHS}$ (both $P<0.05$ ). $\mathrm{H}_{2} \mathrm{~S}$ concentrations in WT $+\mathrm{I} / \mathrm{R}$ + NaHS were remarkably elevated compared with the SR-A ${ }^{--}+\mathrm{I} / \mathrm{R}$ group (all $P<0.05$ ). No significant difference was found between the SR-A ${ }^{--}+\mathrm{I} / \mathrm{R}+\mathrm{NaHS}$ group and the SR-A $\mathrm{A}^{--}+\mathrm{I} / \mathrm{R}$ group $(P>0.05)$ (Fig. 2).

Comparison of the levels of the inflammatory factors $I L-6$ and TGF- $\beta$ in renal tissues among the six groups

The qRT-PCR and Western blotting results showed no significant differences in IL-6 or TGF- $\beta$ mRNA or protein expression between the SR-A ${ }^{-/}+$sham group and the $\mathrm{WT}+$ sham 
Fig. 2. $\mathrm{H}_{2} \mathrm{~S}$ concentration in the renal tissues of rats in different groups $24 \mathrm{~h}$ after ischemia/reperfusion $(\mathrm{n}=8)$. Notes: ${ }^{*} P$ $<0.05$ compared with the WT + sham group; ${ }^{*} P<0.05$ compared with the WT + I/R group; $\&, P<0.05$ compared with the SR-A-/-+ I/R group.

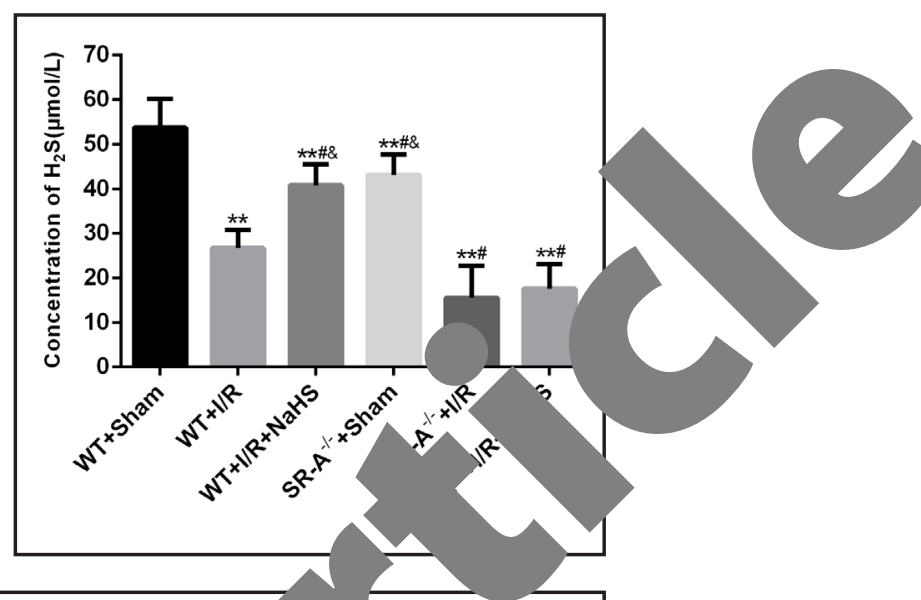

Fig. 3. Detection of mRNA and protein levels of IL- 6 and TGF- $\beta$ in rats of different groups $24 \mathrm{~h}$ after ischemia/reperfusion ( $\mathrm{n}=$ 8). Notes: A, qRT-PCR was used to detect the mRNA expression of IL- 6 in rats from different groups $24 \mathrm{~h}$ after ischemia/reperfusion. $B$, qRT-PCR was used to detect the mRNA expression of TGF- $\beta$ in rats from different groups $24 \mathrm{~h}$ after ischemia/reperfusion. C, Densitometry for IL-6 protein was determined in rats of different groups $24 \mathrm{~h}$ after ischemia/reperfusion. $D$, Densitometry for TGF- $\beta$ pro was determined in rats of diffe groups $24 \mathrm{~h}$ after ischemia/ fusion. E, Western blot used to detect the protei IL- 6 and TGF- $\beta$ in rats of groups $24 \mathrm{~h}$ aft fusion. ${ }^{*} P<0$ $0.05 \mathrm{com}$ red $\mathrm{y}$
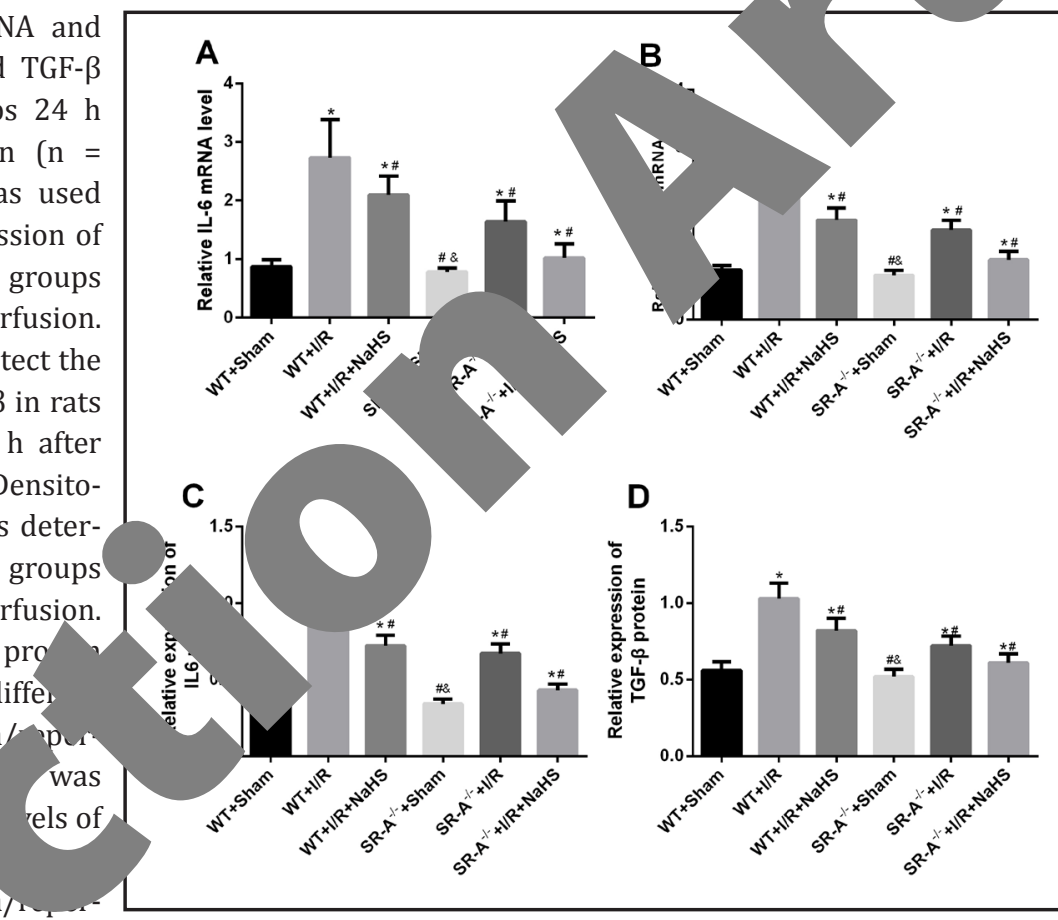

yp . Yfter I/R (all $P>0.05$ ). The mRNA and protein levels of IL- 6 and TGF- $\beta$ were ifican Acreased $24 \mathrm{~h}$ after I/R in the WT + I/R group compared with the WT + sham NI $P<0.05)$. The mRNA and protein levels of IL- 6 and TGF- $\beta$ were significantly dea d $24 \mathrm{~h}$ after I/R in the WT + I/R + NaHS, SR-A $\%+$ I/R and SR-A $\%+$ I/R + NaHS groups compared with the WT $+\mathrm{I} / \mathrm{R}$ group (all $P<0.05)$. The mRNA and protein levels of IL-6 and $F-\beta$ in the SR-A ${ }^{-/}+\mathrm{I} / \mathrm{R}$ group were higher than those in the SR-A $\mathrm{A}^{-/}+$sham group $(P<0.05)$. so marked difference in the mRNA and protein levels of IL- 6 and TGF- $\beta$ were observed between the SR-A $\mathrm{A}^{-1}+\mathrm{I} / \mathrm{R}+\mathrm{NaHS}$ group and the SR-A ${ }^{-1}+\mathrm{I} / \mathrm{R}$ group $(P>0.05)$ (Fig. 3).

Comparison of the apoptosis indexes of renal tissues among the six groups

There was no significant difference of the apoptotic index between the SR-A $\%$ + sham group and the WT + sham group $24 \mathrm{~h}$ after I/R $(P>0.05)$. The apoptotic index was remarkably increased in the WT + I/R group compared with the WT + sham group $24 \mathrm{~h}$ after $\mathrm{I} / \mathrm{R}(P<0.05)$. The apoptotic indexes were significantly decreased $24 \mathrm{~h}$ after I/ $\mathrm{R}$ in the WT

\section{KARGER}


Fig. 4. Detection of apoptosis levels in rats of different groups $24 \mathrm{~h}$ after ischemia/reperfusion using TUNEL (n $=8$ ). Notes: ${ }^{*} P<0.05$ compared with the WT + sham group; ${ }^{*} P<0.05$ compared with the WT + I/R group; ${ }^{\&} P<0.05$ compared with the SR-A ${ }^{-/+}$ I/R group.

$+\mathrm{I} / \mathrm{R}+\mathrm{NaHS}$ and SR-A $\%$ + sham groups compared with the WT + I/R group (all $P<0.05$ ). The apoptotic indexes of the $\mathrm{WT}+\mathrm{I} / \mathrm{R}+\mathrm{NaHS}$ and SR-A ${ }^{-/}+$ $\mathrm{I} / \mathrm{R}$ groups were remarkably elevated compared with that of the WT + sham group (both $P$ $<0.01$ ); no marked difference in the apoptotic index was observed between the SR-A ${ }^{-/}+$ $\mathrm{I} / \mathrm{R}+\mathrm{NaHS}$ group and the SR-A / + I/R group $(P>0.05)$ (Fig. 4).

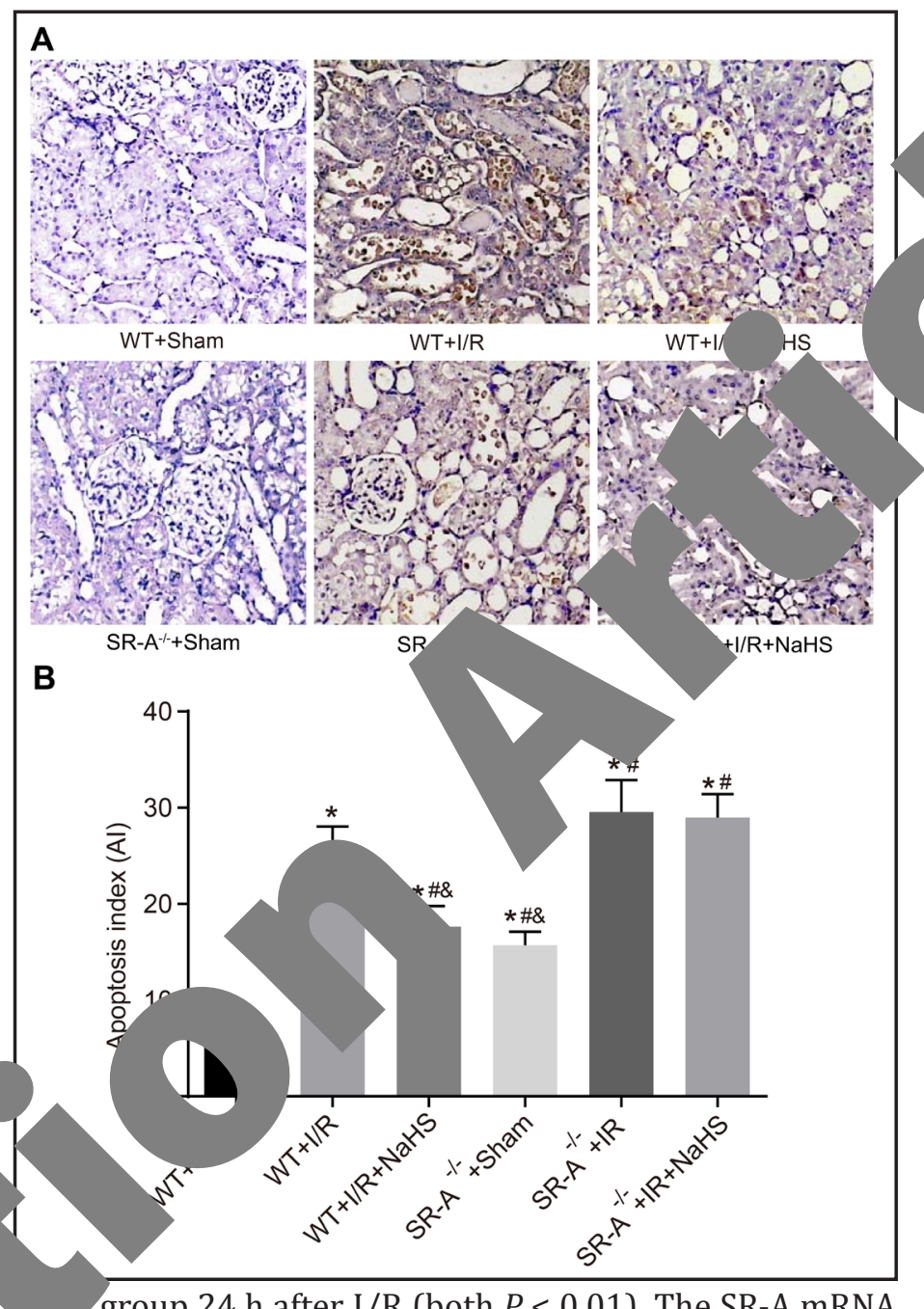

Comparison of SR-A expression in the renal tis sues of rats among the si. groups

The SR-A mRNA and tein levels were signifi. ly decreased in the WT+ group compared with and protein levels $\mathrm{W}$ $\mathrm{I} / \mathrm{R}$ and $\mathrm{SR}-\mathrm{A}^{-/}+\mathrm{I} / \mathrm{R}+$ the levels in ignificantly decreased $24 \mathrm{~h}$ after I/R in the SR-A $\%+$ sham, SR-A $\%+$ aps compared with the WT + I/R group $24 \mathrm{~h}$ after I/R, while I/ $/$ _ vaHS were obviously elevated (all $P<0.05$ ) (Fig. 5).

Cor aris of stress-autophagy levels of rats among the six groups

ata. d that there were no significant differences in the mRNA and protein level autophagy genes LC3 II/I, p-eIF2 $\alpha$ and P62 between the WT + sham group and SR-h ham group $24 \mathrm{~h}$ after I/R (all $P>0.05$ ). The protein levels of LC3I/II and p-eIF $2 \alpha$ WT /R group, WT + I/R + NaHS group, SR-A ${ }^{--}+\mathrm{I} / \mathrm{R}$ group, and SR-A $\mathrm{A}^{--}+\mathrm{I} / \mathrm{R}+\mathrm{NaHS}$ g significantly elevated compared with those in the WT + sham group $24 \mathrm{~h}$ after VR, w. ne the expression of $\mathrm{P} 62$ was apparently reduced (all $P<0.01$ ). The mRNA and protein 1 vels of LC3 II/I and p-eIF2 $\alpha$ were significantly lower than those in the WT + IR group $24 \mathrm{~h}$ cer I/R. The levels in the WT $+\mathrm{I} / \mathrm{R}+\mathrm{NaHS}$ and SR-A $\%+\mathrm{I} / \mathrm{R}+\mathrm{NaHS}$ groups were significantly reduced, but the trend for P62 was the opposite (all $P<0.05$ ). The autophagy in the SR-A ${ }^{-}$ $1-+\mathrm{I} / \mathrm{R}$ group was higherthan that in the SR-A $\%+$ sham group, and no marked differences in the protein levels of LC3 II/I, p-eIF2 $\alpha$ and P62 were observed between the SR-A ${ }^{-1}+$ I/R + NaHS group and the SR-A $\%+$ I/R group (all $P>0.05$ ) (Fig. 6A). Electron microscopy was used to observe autophagosome ultrastructure, and a large quantity of double-membraned autophagosomes was observed near the cell nuclei in the WT + I/R group (white arrow). A small amount of autophagosomes was observed near the cell nuclei in the WT + I/R + NaHS, $\mathrm{SR}^{-} \mathrm{A}^{--}+\mathrm{I} / \mathrm{R}$ and $\mathrm{SR}-\mathrm{A}^{-/}+\mathrm{I} / \mathrm{R}+\mathrm{NaHS}$ groups (white arrows). However, no autophagosomes

\section{KARGER}


Fig. 5. The expression of SR-A in rats of different groups $24 \mathrm{~h}$ after ischemia/reperfusion $(\mathrm{n}=5)$. Notes: A, Western blotting was used to detect the expression of SR-A protein in rats of different groups $24 \mathrm{~h}$ after ischemia/reperfusion. B, qRT-PCR was used to detect the mRNA expression of SR-A in the renal tissues of rats in different groups $24 \mathrm{~h}$ after ischemia/reperfusion. ${ }^{*} P<0.05$ compared with the WT + sham group; ${ }^{\#} P<0.05$ compared with the WT + I/R group.

were found in the WT + sham or SR-A $\%$ + sham groups (Fig. 6B). Additionally, qRT-PCR was used to detect ER stress pathway-related genes (Fig. 6C). The levels of the ER stress pathway genes GRP78, GPR94, ATF4, IRE1, XBP1, ATF6, and eIF2 $\alpha$ were significantly increased in the WT + I/R group, WT + I/R

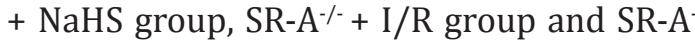
I- + I/R + NaHS group while decreased after the administration of NaHS compared with the WT + sham group $(P<0.05)$. I/R also induced the activation of genes involved in the ER stress pathway in the rats with SR-A knockdown. The expression of the al genes was not statistically cignifi different between the SR-A $/ / \mathrm{P}+$ group and the $\mathrm{SR}-\mathrm{A}^{-/}+\mathrm{I} / \mathrm{R}$ gr $0.05)$, which demonstrat H2S regulates SR-A ER stre ough

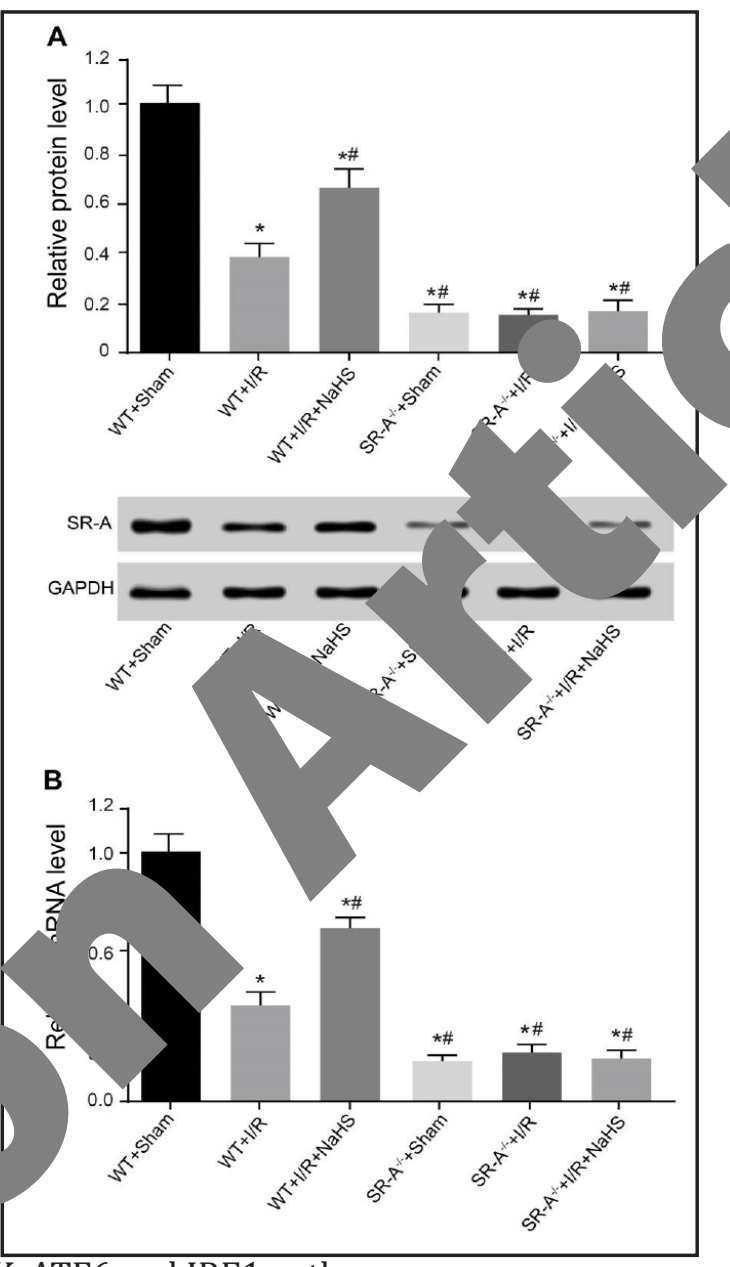

\section{Discussion} decre rina cein, BUN, SCR and MDA, increase SOD activity, and inhibit inflammation, apop. and ER stress/autophagy, which implies that exogenous $\mathrm{H}_{2} \mathrm{~S}$ may attenuate renal

We fo, 1 d that urinary protein, BUN and SCR were increased in renal IRI, while SR-A ge kout, with increased $\mathrm{H}_{2} \mathrm{~S}$, showed reduced levels of urinary protein. BUN and SCR ncreased SOD activity significantly, thus providing protective effects for renal IRI. Elevated 1 -els of proteins in the urine have been widely regarded as a highly important determinant renal complications in a large variety of populations and settings [28]. BUN and SCR are both considered specific markers to measure kidney function, and BUN concentration has been correlated with adverse outcomes. BUN has also been included in myocardial infarction risk prediction models, and the measurement of SCR has been used to diagnose kidney disease $[29,30]$. SOD has been considered to play a protective role in renal IRI and is widely expressed in the kidneys and the vasculature. It might be considered as the most relevant molecule against ischemia-induced changes in the kidney, including the maintenance of renal blood flow [31]. Other than increased urinary protein, BUN and SCR may influence multi-organ damage, and SOD can decrease oxidative stress and injury and improve the

\section{KARGER}


Fig. 6. Detection of endoplasmic reticulum stress/autophagy in rats of different groups $24 \mathrm{~h}$ after ischemia/reperfusion $(\mathrm{n}=5)$. Notes: A, Western blotting was used to detect LC3 II/I and P62 protein levels in rats of different groups 24 $\mathrm{h}$ after ischemia/reperfusion. B, Electron microscopy was used to observe the structure of autophagosomes in the renal tissues of rats from different groups, and the white arrows represent the autophagosomes with bilayer membrane structures. C, qRT-PCR was used to detect the mRNA expression of GRP78, GPR94, ATF4, IRE1, XBP1, ATF6, and eIF $2 \alpha$ in the renal tissues of rats in different groups $24 \mathrm{~h}$ after ischemia/reperfusion. ${ }^{*} P<0.05$ compared with the $\mathrm{WT}+$ sham group; ${ }^{\#} P<0.05$ compared with the WT + I/R group; $\& P<0.05$ compared with the SR-A $\%+$ I/R group.
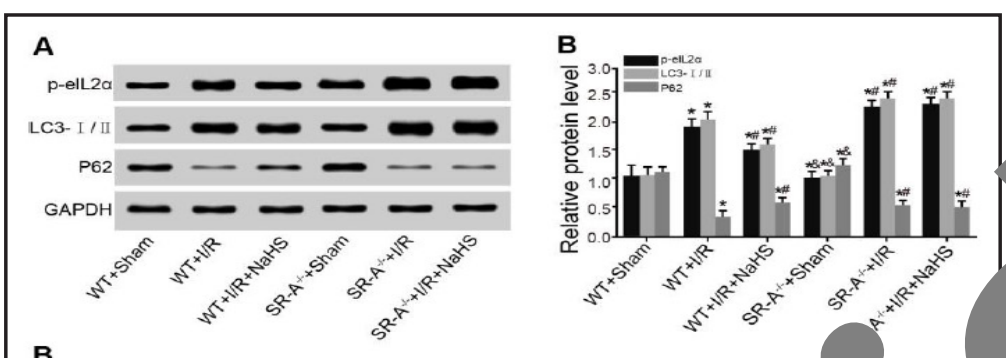

B
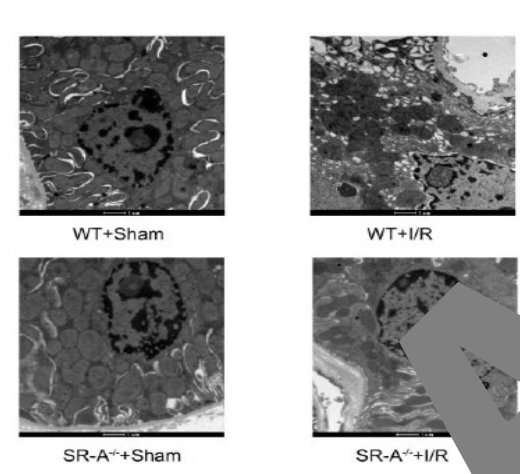

C
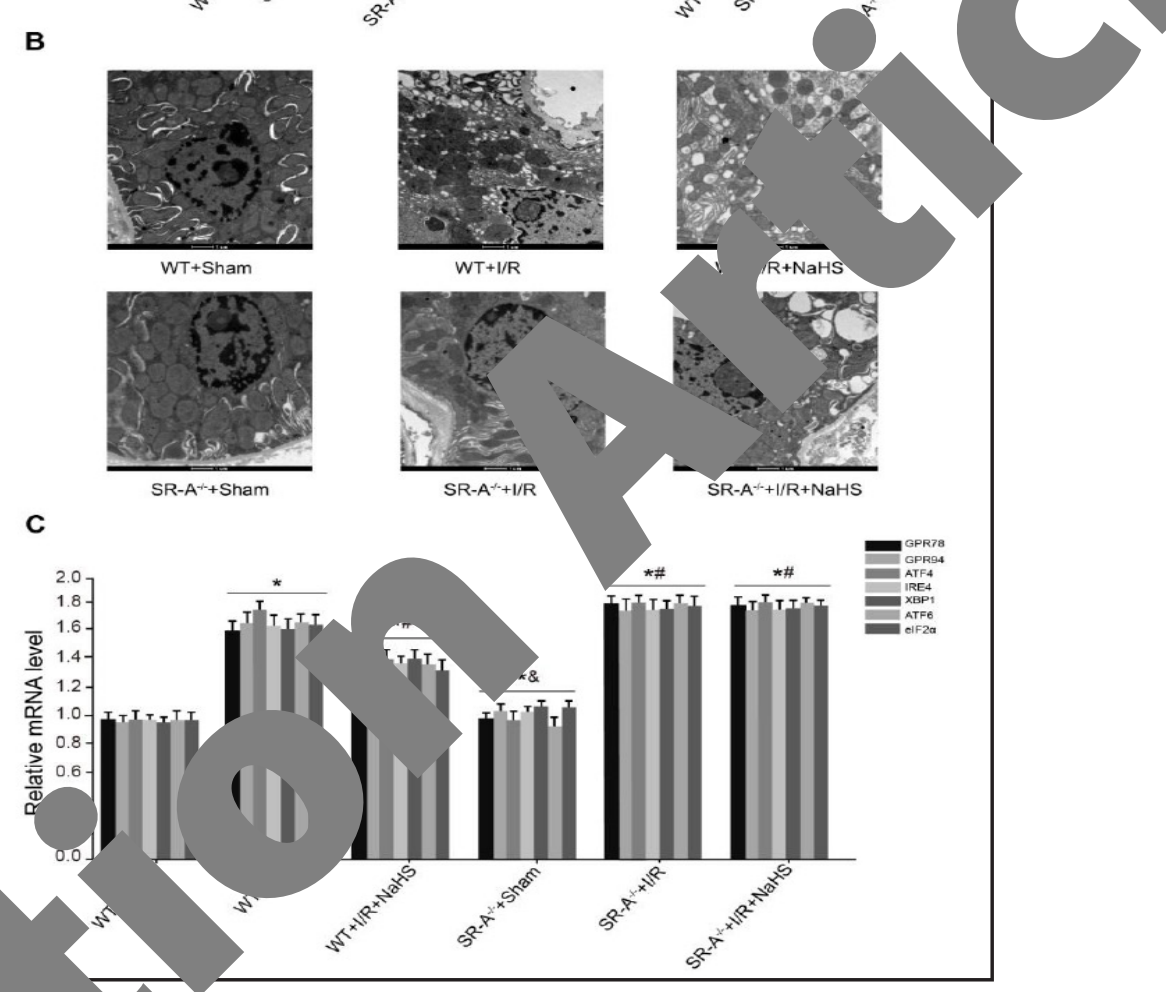

recovery of renal bloo low g renal I/R. SR-A is a critical molecule to increase oxidative stress, infla ration, a r. ibrosis in the pathogenesis of chronic kidney disease, and its deficiency car knockout may the urinary protein, BUN and SCR and positively modulate SOD tect ice from progressive nephropathy, indicating that $S R-A$ gene excretion $\mathrm{t}^{\mathrm{s}}$ or $\mathrm{r}$ and vascular actions in the kidney, and it can also alleviate renal IRI via ioxi + r-apoptotic, and anti-inflammatory effects, which the exact opposite of th es of ry protein. BUN and SCR are associated with the role of SOD in renal in vry, ving that $\mathrm{H}_{2} \mathrm{~S}$ may inhibit urinary protein, BUN and SCR to increase SOD [25]. rahav kul et al. have suggested that the level of SCR in animals with SR deficiency was hat of control animals, indicating better-maintained kidney function [32]. $\mathrm{H}_{2} \mathrm{~S}$ therapy co. ed to a remarkable reduction in kidney injury, with reduced SCR levels, and it rotects glomerular function, thus providing a promising new approach to ameliorate renal
[34]. Because urinary protein levels, BUN and SCR are renal injury markers that are all creased in renal injury, it is not difficult to deduce that they are positively correlated with each other [28]. Once SCR is decreased, urinary protein and BUN will also show a downward trend [35]. The studies mentioned above are all in accordance with our result that increased $\mathrm{H}_{2} \mathrm{~S}$ or SR deficiency can lead to the reduction of urinary protein, BUN and SCR. Thus, renal IRI may be improved.

Our study also found that the mRNA and protein levels of IL- 6 and TGF- $\beta$ were higher in renal IRI, while $S R-A$ gene knockout and increased $\mathrm{H}_{2} \mathrm{~S}$ could lower them, thereby attenuating renal IRI. As a pleiotropic cytokine, IL-6 produced by tubular epithelial cells primarily participates in regulating immune responses and exacerbating inflammatory 
responses, and its levels in renal I/R were increased, which is regarded as a predictor of sustained and acute renal failure [36]. TGF- $\beta$ is part of a large family of cytokines that regulate cellular responses in development and tissue repair, and TGF- $\beta$ activation can lead to fibrogenic foci and trigger fibrogenesis in chronic renal injury [37]. The levels of IL-6 and TGF- $\beta$ were higher in patients with nephropathy, promoting inflammation or fibrosis, while SR-A deficiency helped inhibit the TGF- $\beta$ pathway and reduce inflammation to attenuate the injury [33]. IL-6 is closely associated with inflammation, suggesting that SR-A deficiency may negatively affect the expression of IL- 6 and TGF- $\beta$ [38]. $\mathrm{H}_{2} \mathrm{~S}$ has been reported to bo involv in the negative regulation of inflammatory responses related to a variety of cytc es, th suggesting that $\mathrm{H}_{2} \mathrm{~S}$ has the potential to decrease IL- 6 and TGF- $\beta$ [39]. The findings et al. suggested that $S R-A$ gene knockout protects mice from progressive suppressing the TGF- $\beta$ pathway [33]. When $\mathrm{H}_{2} \mathrm{~S}$ was decreased, IL-6 levels suggesting their negative correlation [39]. We also found that GRP78, eIF2 ATF4, IRE1, XBP1 and ATF6 were all expressed more highly in renal IPI knockout increased $\mathrm{H}_{2} \mathrm{~S}$-inhibited autophagy by lowering their express have demonstrated that the ER is involved in the cell death $r$ nal con $n$ of LC3 I/II and increased expression of P62 [40]. GRP78, CHOP, XBP1s, are the that are often analyzed to investigate the mechanism of the str diated apoptotic pathway [41]. The up-regulation of GRP78 is involved in at sy aucivation, and the phosphorylation of eIF2 $\alpha$ is essential for autophagy. LC3 has be sed as a specific marker to monitor autophagy, and the amount of LC3-II (conjugated form o 3 ) is closely correlated with the number of autophagosomes [42-44]. $\mathrm{H}_{2} \mathrm{~S}$ opress ER stress, and ER stress is able to induce autophagy. Therefore, it is reason to tude that $\mathrm{H}_{2} \mathrm{~S}$ can also suppress autophagy. As GRP78, eIF2 $\alpha$ and LC3-II are posic asso ced with autophagy, it is logical to deduce that $\mathrm{H}_{2} \mathrm{~S}$ can help decrease the le of 4 eIF2 $\alpha$ and LC3-II $[45,46]$.

In summary, our findings may off However, the concrete mechar of ho diates $\mathrm{H}_{2} \mathrm{~S}$ remains unknown, and further studies are needed to develop mis tudy

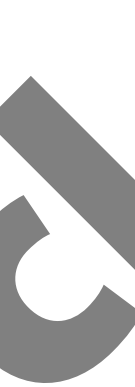
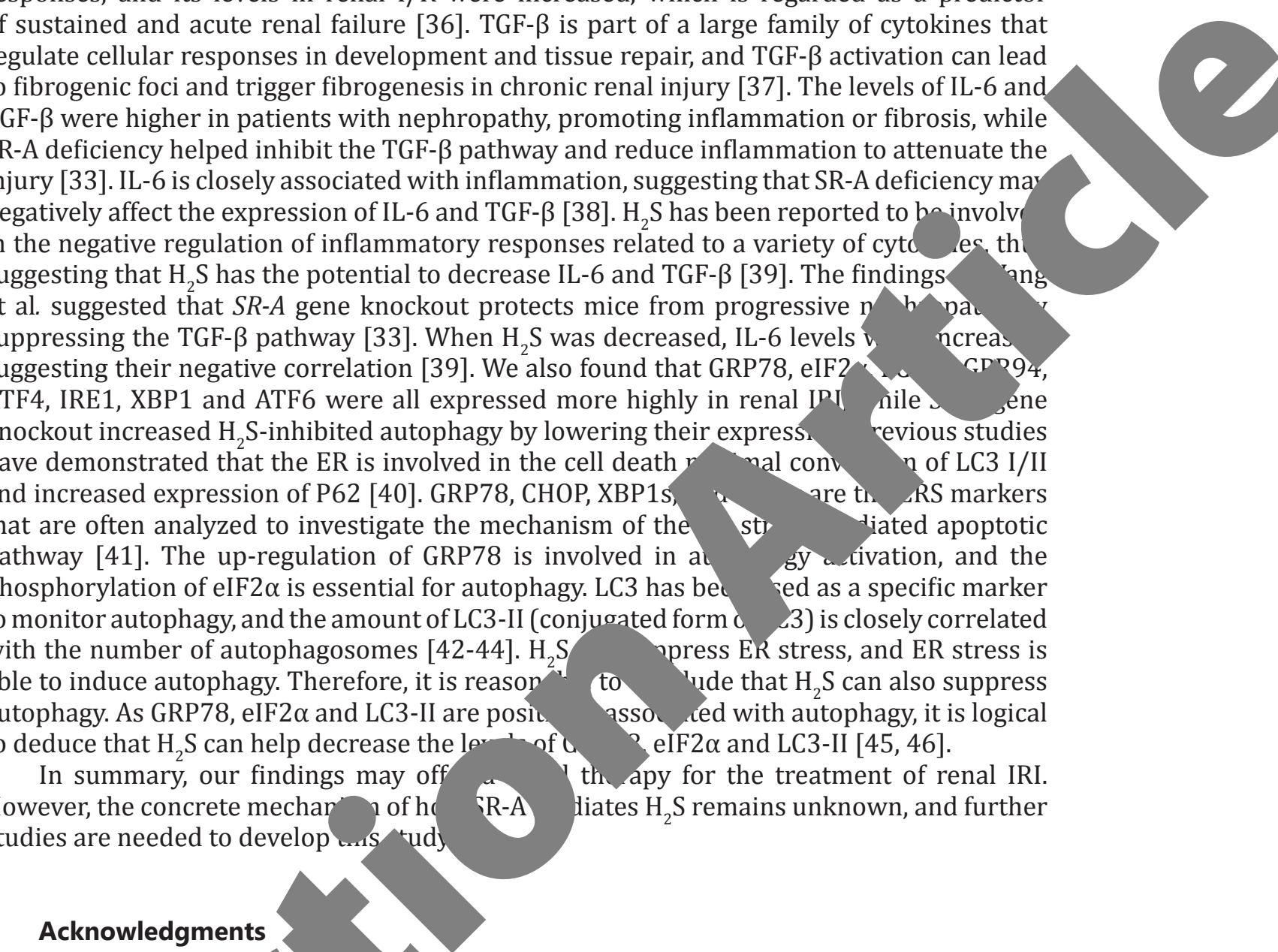

The authors wan show the appreciation to all who helped edit the paper.

In Kidney cells recapitulates various phenotypic aspects of kidney ischemia-reperfusion injury. J Am Soc Nephrol 2004;15:1844-1852.

Wu H, Chen G, Wyburn KR, Yin J, Bertolino P, Eris JM, Alexander SI, Sharland AF, Chadban SJ: TLR4 activation mediates kidney ischemia/reperfusion injury. J Clin Invest 2007;117:2847-2859.

Mehrabi A, Mood Zh A, Sadeghi M, Schmied BM, Muller SA, Welsch T, Kuttymuratov G, Wente MN, Weitz J, Zeier M, Morath C, Riediger C, Schemmer P, Encke J, Buchler MW, Schmidt J: Thymoglobulin and ischemia reperfusion injury in kidney and liver transplantation. Nephrol Dial Transplant 2007;22 Suppl 8:viii54viii60.

Beiras-Fernandez A, Thein E, Chappel D, Gallego R, Fernandez-Roel D, Kemming G, Hammer C: Polyclonal anti-thymocyte globulins influence apoptosis in reperfused tissues after ischaemia in a non-human primate model. Transpl Int 2004;17:453-457. 


\section{Cellular Physiology Cell Physiol Biochem 2017;41:2461-2474

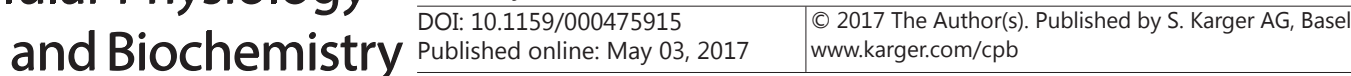

Ling et al.: $\mathrm{H}_{2} \mathrm{~S} \& \mathrm{SR}-\mathrm{a}$ Reduce Ischemia/Reperfusion Injury

-5 Aydin Z, van Zonneveld AJ, de Fijter JW, Rabelink TJ: New horizons in prevention and treatment of ischaemic injury to kidney transplants. Nephrol Dial Transplant 2007;22:342-346.

6 Wu H, Huang T, Ying L, Han C, Li D, Xu Y, Zhang M, Mou S, Dong Z: MiR-155 is Involved in Renal IschemiaReperfusion Injury via Direct Targeting of FoxO3a and Regulating Renal Tubular Cell Pyroptosis. Cell Physiol Biochem 2016;40:1692-1705.

7 Li Y, Zhong D, Lei L, Jia Y, Zhou H, Yang B: Propofol Prevents Renal Ischemia-Reperfusion Injury via Inhibiting the Oxidative Stress Pathways. Cell Physiol Biochem 2015;37:14-26.

8 Preising C, Schneider R, Bucher M, Gekle M, Sauvant C: Regulation of Expression of Renal Organic Anion Transporters OAT1 and OAT3 in a Model of Ischemia/Reperfusion Injury. Cell Physiol Biocher 13.

-9 Decuypere JP, Ceulemans LJ, Agostinis P, Monbaliu D, Naesens M, Pirenne J, Jochmans I: Ay^ophagy Kidney: Implications for Ischemia-Reperfusion Injury and Therapy. Am J Kidney Dis 201

10 Liu XH, Zhang ZY, Sun S, Wu XD: Ischemic postconditioning protects myocardium from is reperfusion injury through attenuating endoplasmic reticulum stress. Shock 2008;30: Guan X, Qian Y, Shen Y, Zhang L, Du Y, Dai H, Qian J, Yan Y: Autophagy protects rena ${ }^{\prime}$ ischemia / reperfusion injury in a time-dependent manner. Cell Physiol Biochem 20

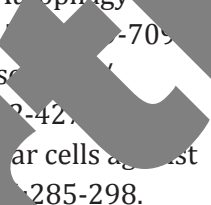

12 Zhang HY, Wang ZG, Lu XH, Kong XX, Wu FZ, Lin L, Tan X, Ye LB, Xiao ${ }_{1}$ '9smic re stress: relevance and therapeutics in central nervous system diseases. Mol

13 Petrovski G, Das S, Juhasz B, Kertesz A, Tosaki A, Das DK: Cardioprotec stress-induced autophagy. Antioxid Redox Signal 2011;14:2191-2200.

14 Bobrovnikova-Marjon E, Pytel D, Riese MJ, Vaites LP, Singh N, Koretzky Gs intrinsic lipid kinase activity to generate phosphatidic acid, mediate Akt ac ion, and promote adipocyte differentiation. Mol Cell Biol 2012;32:2268-2278.

15 Birkenfeld AL, Lee HY, Majumdar S, Jurczak MJ, Camp M, Zhang D, Weismann D, Arafat AM, Pfeiffer AF, Liesk רdom $\rho$, Ron D, Samuel VT, Shulman GI:

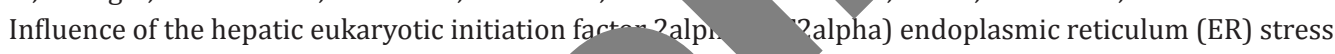
response pathway on insulin-mediated ER s at peripheral glucose metabolism. J Biol Chem 2011;286:36163-36170.

16 Ni M, Zhang Y, Lee AS: Beyond t ndopla therapeutic targeting. Biochem $\mathrm{J} 2 \mathrm{C}$ Mahfoudh-Boussaid A, Zao Hadj-Ayed K, Miled AH, Ghoul-Mazgar S, Saidane-Mosbahi D, Rosello-Catafau J, Ben A. bi H: A. tion of endoplasmic reticulum stress and mitochondrial injury in kidney with ischer. on tioning application and trimetazidine treatment. J Biomed Sci 2012;19:71.

18 Yorimitsu T, Nair U, 2006;281:30299-30

Z, Klionsky D]: Endoplasmic reticulum stress triggers autophagy. J Biol Chem

Kellry Jь, Ozment TR, Li C, Schweitzer JB, Williams DL: Scavenger receptor-A (CD204): a two-edged sword th and disease. Crit Rev Immunol 2014;34:241-261.

Jonansen D, Ytrehus K, Baxter GF: Exogenous hydrogen sulfide (H2S) protects against regional myocardial ischemia-reperfusion injury--Evidence for a role of K ATP channels. Basic Res Cardiol 2006;101:53-60. Ji Y, Pang QF, Xu G, Wang L, Wang JK, Zeng YM: Exogenous hydrogen sulfide postconditioning protects isolated rat hearts against ischemia-reperfusion injury. Eur J Pharmacol 2008;587:1-7.

Wu D, Wang J, Li H, Xue M, Ji A, Li Y: Role of Hydrogen Sulfide in Ischemia-Reperfusion Injury. Oxid Med Cell Longev 2015;2015:186908.

-26 Gerasimova E, Lebedeva J, Yakovlev A, Zefirov A, Giniatullin R, Sitdikova G: Mechanisms of hydrogen sulfide (H2S) action on synaptic transmission at the mouse neuromuscular junction. Neuroscience 2015;303:577585. 


\section{Cellular Physiology Cell Physiol Biochem 2017;41:2461-2474 \begin{tabular}{l|l} 
DOI: 10.1159/000475915 \\
and Biochemistry
\end{tabular} $\begin{aligned} & \text { Publisned onnine:1 } 2017 \text { The Thy Author(s). Published by S. Karger AG, Basel } \\
& \text { www.karger.com/cpb }\end{aligned}$

Ling et al.: $\mathrm{H}_{2} \mathrm{~S} \& \mathrm{SR}-\mathrm{a}$ Reduce Ischemia/Reperfusion Injury

27 Bian Y, Deng C, Li W, Lei Z, Li Y, Li X: A Comparative Study on the Biological Characteristics of Human Adipose-Derived Stem Cells from Lipectomy and Liposuction. PLoS One 2016;11:e0162343.

-28 Lambers Heerspink HJ, Gansevoort RT, Brenner BM, Cooper ME, Parving HH, Shahinfar S, de Zeeuw D: Comparison of different measures of urinary protein excretion for prediction of renal events. J Am Soc Nephrol 2010;21:1355-1360.

-29 Kirtane AJ, Leder DM, Waikar SS, Chertow GM, Ray KK, Pinto DS, Karmpaliotis D, Burger AJ, Murphy SA Cannon CP, Braunwald E, Gibson CM, Group TS: Serum blood urea nitrogen as an independent marker of subsequent mortality among patients with acute coronary syndromes and normal to mildly reduced glomerular filtration rates. J Am Coll Cardiol 2005;45:1781-1786.

-30 Chang YK, Lee SJ, Chung BH, Kim YO, Shin YS: Renal histology in patients with elevated serum creat ne and concurrent normal urinalysis. Clin Nephrol 2012;77:283-289.

31 Schneider MP, Sullivan JC, Wach PF, Boesen EI, Yamamoto T, Fukai T, Harrison DG, Polloc Protective role of extracellular superoxide dismutase in renal ischemia/reperfusion injur 2010;78:374-381.

Leelahavanichkul A, Bocharov AV, Kurlander R, Baranova IN, Vishnyakova TG, Sou7 Vaisman B, Amar M, Sviridov D, Chen Z, Remaley AT, Csako G, Patterson AP, Yuen PS, Class B scavenger receptor types I and II and CD36 targeting improve in mice. J Immunol 2012;188:2749-2758.

-33 Wang W, He B, Shi W, Liang X, Ma J, Shan Z, Hu Z, Danesh FR: Deletion from progressive nephropathy independent of lipid control during diet2012;81:1002-1014.

-34 Hunter JP, Hosgood SA, Patel M, Rose R, Read K, Nicholson MI-Effects of hy sen sulphide in an experimental model of renal ischaemia-reperfusion injur $\quad$ rg 2012;99:1665-1671.

-35 Maimoona A, Naeem I, Saddiqe Z, Jameel K: A review of traceutical and clinical aspects of French maritime pine bark extract. J Ethnopharmaco $133: 2,277$.

36 Patel NS, Chatterjee PK, Di Paola R, Mazzon E, Brist-D, Du A, Cuzzocrea S, Thiemermann C: Endogenous interleukin-6 enhances the ren fun and inflammation caused by ischemia/ reperfusion. J Pharmacol Exp Tb 2005;3 Bottinger EP: TGF-beta in rena ry and 170Nephrol 2007;27:309-320.

- 38 Kalliakmani P, Nakopoulou L, Tsak a roly apotiriou M, Goumenos DS: Urinary interleukin-6 (IL-6) and transforming gr beta) levels in corticosteroidtreated patients with IgA nephropathy. Clin Nephro $\quad 6: 144$

39 Li T, Zhao B, Wang C, Wano 6, IL-8 and IL-10 leve Me pla pulmonary tissue of rats with acute lung injury. Exp Biol Med (Maywood) 2008;23 81-1087.

40 Suparji NS, Chan G, S d NM, In LL, Awang K, Hasima Nagoor N: Geranylated 4-Phenylcoumarins Exhibit Anti Eft Human Prostate Cancer Cells through Caspase-Independent Mechanism. PLoS Onf 16 151472.

-41 YangY, Sum na eng X, Ma H, Ma W, Wang Z, Pei X, Wang Y: Endoplasmic reticulum stress-mediated apc ic p. Involved in corpus luteum regression in rats. Reprod Sci 2015;22:572-584.

42 XY, Zha Song DD, Zhou J, Han R, Qin ZH, Sheng R: Endoplasmic reticulum chaperone GRP78 is

in in autophagy activation induced by ischemic preconditioning in neural cells. Mol Brain 2015;8:20.

Weng Wang D, Weiss S, Zhong H, Osman I, Gardner LB: Phosphorylation of eIF2alpha triggered

by TO 1 C1 inhibition and PP6C activation is required for autophagy and is aberrant in PP6C-mutated oma. Sci Signal 2015;8:ra27.

Kuma A, Matsui M, Mizushima N: LC3, an autophagosome marker, can be incorporated into protein aggregates independent of autophagy: caution in the interpretation of LC3 localization. Autophagy 2007;3:323-328.

Li MH, Tang JP, Zhang P, Li X, Wang CY, Wei HJ, Yang XF, Zou W, Tang XQ: Disturbance of endogenous hydrogen sulfide generation and endoplasmic reticulum stress in hippocampus are involved in homocysteine-induced defect in learning and memory of rats. Behav Brain Res 2014;262:35-41.

-46 Yorimitsu T, Klionsky DJ: Endoplasmic reticulum stress: a new pathway to induce autophagy. Autophagy 2007;3:160-162. 